\title{
Antagonism is the Predominant Effect of Herbicide Mixtures USED FOR IMIDAZOLINONE-RESISTANT BARNYARDGRASS (Echinochloa crus-galli) CONTROL ${ }^{1}$
}

\author{
Antagonismo é o Efeito Predominante em Misturas de Herbicidas Utilizados para o Controle de \\ Capim-arroz (Echinochloa crus-galli) Resistente a Imidazolinonas
}

MATZENBACHER, F.O. ${ }^{2}$, KALSING, A. ${ }^{2}$, DALAZEN, G. ${ }^{3}$, MARKUS, C. ${ }^{3}$, and MEROTTO JR. , A. ${ }^{3}$

\begin{abstract}
Herbicides mixtures are used in many situations without the adequate knowledge related with the effect on major target weeds. The objective of this study was to evaluate the effects of different herbicides mixtures used in irrigated rice in order to establish the adequate combinations for the prevention and management of herbicide resistance in barnyardgrass (Echinochloa crus-galli). Three experiments were performed at field conditions with all major post-emergent herbicides used in irrigated rice in Brazil. The first experiment was performed with barnyardgrass resistant to imidazolinone herbicides and herbicides applied at label rates. The second and third experiments were performed with barnyardgrass resistant and susceptible to imidazolinone herbicides applied at doses of 50 or $75 \%$ of the label rates. The occurrence of additive, synergistic and antagonistic effects was identified at 18, 18 and 64\%, respectively, among the total of 50 different associations of herbicide and rates evaluated. In general, the mixture of ACCase inhibitors with ALS inhibitors, quinclorac, clomazone + propanil or thiobencarb resulted in antagonism. Sinergic mixtures were found in clomazone with propanil + thiobencarb, profoxydim with cyhalofop-butyl or clomazone, and quinclorac with imazapyr + imazapic, bispyribac-sodium or cyhalofop-butyl. The mixtures of quinclorac with profoxydim were antagonic. Rice grain yield varied according to the efficiency of weed control. Seveveral mixtures were effective for imidazolinone resistant barnyardgrass control.
\end{abstract}

Keywords: ALS inhibitors, irrigated rice, interaction, synergism.

RESUMO - Em diversas situações as associações de herbicidas são realizadas sem o conhecimento do efeito sobre as principais plantas alvo da aplicação. O objetivo deste trabalho foi avaliar o efeito da associação de herbicidas utilizados na cultura do arroz irrigado, de forma a estabelecer opções de combinações de herbicidas que possam ser utilizadas na prevenção e manejo da resistência de capim-arroz. Foram realizados três experimentos em condições de campo, com os principais herbicidas utilizados em pós-emergência na cultura do arroz irrigado no Brasil. O primeiro experimento foi realizado com capim-arroz resistente a imidazolinonas e herbicidas em doses recomendadas. O segundo e o terceiro experimentos foram realizados com capim-arroz suscetivel a imidazolinonas e herbicidas em doses de 50 ou 75\% da dose máxima recomendada. A ocorrência de aditividade, sinergismo e antagonismo foi observada em 18, 18 e 64\%, respectivamente, em um total de 50 diferentes misturas avaliadas. De forma geral, a mistura de inibidores da ACCase com inibidores de ALS, quinclorac, clomazone ou propanil + thiobencarb, resultaram em antagonismo. Associações sinérgicas foram encontradas em clomazone com propanil + thiobencarb, profoxydim com cyhalofop-butyl ou clomazone, e quinclorac com imazapyr + imazapic, bispyribac-sodium ou cyhalofop-butyl. A associação de quinclorac com profoxydim foi antagônica. O rendimento de grãos variou conforme a eficiência de controle de plantas daninhas, uma vez que nos tratamentos em que a mistura foi sinérgica, obteve-se maior produtividade de grãos. Várias misturas foram eficientes para o controle de capim-arroz resistente a imidazolinonas.

Palavras-chave: inibidores da ALS, arroz irrigado, interação, sinergismo.

Recebido para publicação em 18.2.2015 e aprovado em 30.3.2015.

2 Institut Riograndense of Rice - IRGA. Cachoerinha-RS, Brazil, < felipematzenbacher@gmail.com>; ${ }^{3}$ Universidade Federal do Rio Grande do Sul - UFRGS. Porto Alegre-RS, Brazil. 


\section{INTRODUCTION}

Barnyardgrass (Echinochloa spp.) occurs frequently and with large plant density in irrigated rice, and is one of the main weeds of this crop in Brazil and worldwide. The prejudices caused by barnyardgrass on rice crop include reduced grain yield, decreased harvesting efficiency and increase production costs. Grain yield losses caused by one barnyardgrass plant $\mathrm{m}^{-2}$ are estimated in 4 to $30 \%$, varying according to rice cultivar and sowing and flooding date (Galon et al., 2007). This damage justifies the use of herbicides to control barnyardgrass and other weeds to maintain the desired levels of rice grain yield.

Herbicide resistant barnyardgrass biotypes has been reported in various parts of the world. There are records of six species of Echinochloa resistant to herbicides of nine different mechanisms of action, and in four of these species, Echinochloa crus-galli, Echinochloa phyllopogon, Echinochloa oryzoides and Echinochloa colona, there is resistance to acetolactate synthase (ALS) inhibitors herbicides (Heap, 2014). The large use of imidazolinone herbicides (ALS-inhibitor) in irrigated rice is related with the broad spectrum of control and with the necessity of red rice control (Roso et al., 2010). The use of these herbicides in rice is provided by the imidazolinone resistant rice cultivars. In southern Brazil, the frequente use of ALS-inhibiting herbicides resulted in fast evolution of barnyardgrass biotypes resistant to ALS inhibitors (Matzenbacher et al., 2015). However, these herbicides are important to control other weed species associated with rice, especially red rice, which makes these herbicides key tools for weed management in this crop. These facts justify the necessity of mixtures of ALS inhibitors with other mechanisms of action for weed control in rice.

The rotation of herbicide mechanism of action in different seasons or the mixture of herbicides with different mechanism of action in the same season are among the main alternatives to prevent the occurrence and to control herbicide resistant weed biotypes (Merotto Jr., 2009). The herbicide mixture increases the spectrum of control and prevents the appearance of resistant weeds. However, the mixture of different herbicides may exhibit additive, synergistic or antagonistic responses (Hatzios \& Penner, 1985; Kruse et al., 2001). The additivity occurs when the effect of the observed control is equivalent to the sum of the individual effects; synergism occurs when the observed effect is higher than the isolated effect of the herbicides; and the antagonism occurs when the effect of the association of different herbicides is less than the herbicidal effect of each isolate (Hatzios \& Penner, 1985; Zhang et al., 1995). These interactions occur on the ground, in the spray solution, on the leaf surface, in the tissues responsible for absorption and translocation and in the herbicide site of action. The evaluation of the interaction of different herbicides can be performed by Colby method (Colby, 1967), where the effect of control of herbicides in mixture is compared with the effect of the herbicides used alone. This method was initially developed by Gowing (1959) and later adapted by Limpel et al. (1962), and uses the multiplicative model, which applies to cases where the combination components do not exhibit a similar action. The evaluation of the herbicidal effect of the mixture can be performed using the recommended label dose or sub dose of each herbicide. The use of sub doses enables occurrence of physiological interactions which do not occur when using high doses due to rapid effect.

Herbicide mixtures containing ACCase inhibitors are frequently related with the occurrence of antagonism. Mixtures of fenoxaprop-P-ethyl with imazethapyr, bispyribac-sodium, quinclorac and penoxsulam resulted in antagonism in E. crus-galli (Blouin et al., 2010). The association of imazethapyr with clethodim, fluazifop, quizalofop or sethoxydim reduced the effectiveness of Digitaria sanguinalis, Panicum dichotomiflorum and Brachiaria plantyphylla control, compared with the application of the grass herbicide alone (Myers \& Coble, 1992). Reduction in the efficiency of ACCase-inhibiting herbicides when applied in combination with ALS-inhibitors may be due to reduced absorption (Barnwell \& Cobb, 1994) or translocation of the grass herbicide (Ferreira et al., 1995; Barnes \&Oliver, 2004). Mixtures of ALS- or ACCase-inhibitors with herbicides 
from other mechanisms of action in rice can also result in antagonism for barnyardgrass control. Combinations of fenoxaprop-P-ethyl and carfentrazone reduced the control of E. crus-galli compared to the application of fenoxaprop-P-ethyl isolated (Zhang et al., 2005). The result of the combination of herbicides can vary from weeds with different morphological and physiological characteristics. Synergistic effect were found in the mixture of glyphosate with lactofen to Sida spinosa, Ipomoea lacunosa and E. crus-galli, but was antagonic to Sesbania exaltata (Norris et al., 2001).

Herbicide mixtures are largely used due to potentially result in greater efficacy, increased spectrum of control and reduction of the herbicide dose (Kruse et al., 2001; Moss et al., 2007). The use of mixtures is commonly used by rice growers in Brazil without a technical recommendation in relation to herbicides and rates. However, knowledge about the effect of the combination of herbicides is critical, because mixtures of some herbicides may interact antagonistically and a reapplication could be necessary, increasing production costs, reducing the grain yield potential, and increasing environmental risk. The evaluation of the different mixture of rice herbicides can contribute to increase the rationality of herbicide use for barnyardgrass control. However, the use of the herbicide mixture depends on the official recommendation for each crop and weed specie (Gaziero, 2015). The objective of this study was to evaluate the effects of different herbicides mixtures used in irrigated rice in order to establish the adequate combinations for the prevention and management of herbicide resistance in barnyardgrass.

\section{MATERIAL AND METHODS}

The study of the effect of herbicide mixtures used in irrigated rice was performed based on three experiments carried out at field conditions. In all three experiments sowing occurred in line with spacing of $0.17 \mathrm{~m}$. In the first experiment, the fertilizer was applied at sowing date, in the sowing line with $250 \mathrm{~kg} \mathrm{ha}^{-1}$ of NPK 00-20-30, which provided $50 \mathrm{~kg} \mathrm{P}_{2} \mathrm{O}_{5}$ and $75 \mathrm{~kg} \mathrm{~K}_{2} \mathrm{O}$ ha $^{-1}$. Nitrogen fertilization was divided into two applications of 130 and $17 \mathrm{~kg} \mathrm{ha}^{-1}$ in the formula 46-00-00, at the stages V5 and panicle differentiation (R1 stage) according to Counce et al. (2000). In the second and third experiments, the starter fertilization was $400 \mathrm{~kg} \mathrm{ha}^{-1}$ of NPK 04-17-27, which afforded $16 \mathrm{~kg}$ of $\mathrm{N}, 68 \mathrm{~kg}$ of $\mathrm{P}_{2} \mathrm{O}_{5}$ and $108 \mathrm{~kg} \mathrm{ha}^{-1}$ of $\mathrm{K}_{2} \mathrm{O}$. Nitrogen fertilization was applied at V5 and R1 (Counce et al., 2000) at 75 and $35 \mathrm{~kg} \mathrm{ha}^{-1} \mathrm{~N}$, respectively.

The flood irrigation was performed 3-5 days after the spraying of herbicides. The control of diseases and pests was carried out in a preventive manner with the use of insecticides and fungicides registered for rice cultivation. Herbicide application in both experiments was performed with $\mathrm{CO}_{2}$ pressurized backpack sprayer, with nozzle type 80.01 , calibrated to spray volume of $100 \mathrm{~L} \mathrm{ha}^{-1}$. The application occurred when the barnyardgrass plants were three to four leaves, under temperature ranging from 20 to $26^{\circ} \mathrm{C}$ and relative humidity of $65-75 \%$.

\section{First experiment - barnyardgrass resistant to imidazolinone herbicides}

The experiment was conducted in a rice field infested with barnyardgrass resistant to imidazolinone herbicides located in Palmares do Sul (RS) (Matzenbacher et al., 2013) in a dystrophic solodic Typical Planosol (Streck et al., 2010). The barnyardgrass density quantified in the untreated check plots was of 480 plants $\mathrm{m}^{-2}$. The experiment was carried out using the randomized block design with four replications. Treatments are described in Table 1 . The herbicide rates used correspond to those recommended by the herbicides manufacturers for barnyardgrass control. The sowing of rice was held on November 5, 2010, with a seed density of $100 \mathrm{~kg} \mathrm{ha}^{-1}$ of the cultivar Puitá INTA CL in plots of $7.0 \times 2.0 \mathrm{~m}$.

\section{Second experiment - barnyardgrass susceptible to imidazolinone herbicides applied at low rates}

The experiment was conducted at the Rice Experimental Station in the Institute Riograndense of Rice (EEA-IRGA), in Cachoeirinha, RS, in an area with soil classified as typical dystrophic Haplic Gleysol 
Table 1 - Herbicides treatments evaluated for imidazolinone-resistant barnyardgrass (Echinochloa crus-galli) control. Palmares do Sul-RS, 2010/11

\begin{tabular}{|c|c|c|c|c|c|}
\hline \multicolumn{2}{|c|}{ Active ingredient* } & \multicolumn{2}{|c|}{ Commercial name } & \multicolumn{2}{|c|}{ Dose $\left(\mathrm{g} \mathrm{ha}^{-1}\right)$} \\
\hline Herbicide A & Herbicide B & Herbicide A & Herbicide B & Herbicide A & Herbicide B \\
\hline Quinclorac & - & Facet & - & 375 & - \\
\hline Profoxydim & - & Aura & - & 120 & - \\
\hline Profoxydim & - & Aura & - & 150 & - \\
\hline Imazapyr + imazapic & - & Kifix & - & $105+35$ & - \\
\hline $\begin{array}{l}\text { Imazethapyr + } \\
\text { imazapic }\end{array}$ & - & Only & & $75+25$ & \\
\hline Fenoxaprop-P-ethyl & - & Starice & - & 89.7 & - \\
\hline Clomazone & - & Gamit 360 SC & - & 400 & - \\
\hline Bispyribac-sodium & - & Nominee & - & 50 & - \\
\hline Penoxsulam & - & Ricer & - & 48 & - \\
\hline Quinclorac & Profoxydim & Facet & Aura & 375 & 120 \\
\hline Imazapyr + imazapic & Profoxydim & Kifix & Aura & $105+35$ & 150 \\
\hline Imazapyr + imazapic & Quinclorac & Kifix & Facet & $105+35$ & 375 \\
\hline Fenoxaprop-P-ethyl & Clomazone & Starice & Gamit & 89.7 & 400 \\
\hline Fenoxaprop-P-ethyl & Imazapyr + imazapic & Starice & Kifix & 89.7 & $100+35$ \\
\hline Fenoxaprop-P-ethyl & Bispyribac-sodium & Starice & Nominee & 89.7 & 50 \\
\hline Fenoxaprop-P-ethyl & Imazethapyr + imazapic & Starice & Only & 89.7 & $75+25$ \\
\hline Fenoxaprop-P-ethyl & Penoxsulam & Starice & Ricer & 89.7 & 48 \\
\hline Infested check & - & - & - & - & - \\
\hline
\end{tabular}

* Adjuvant used according to the manufacturer's recommendation.

(Streck et al., 2010). The experiment was performed using the randomized block design with four replications. Treatments are described in Table 2. Herbicide rates corresponded to 50 or $75 \%$ of the maximum dose recommended by the manufacturer. These doses were used to identify the effects of interaction between herbicide simulating situations where the effective rated intercepted by plants are lower than expected due to adverse environmental factors or failure in application technology, and to provide the effect of the herbicide in situations that do not result in death of the plant. The rice sowing was performed in October 8, 2013, with a seed density of $80 \mathrm{~kg} \mathrm{ha}^{-1}$ of the cultivar IRGA 428, which is resistant to imidazolinone herbicides, in plots of $6.5 \times 2.0 \mathrm{~m}$.

\section{Third experiment - imidazolinone susceptible barnyardgrass and herbicides} mixtures applied at $\mathbf{5 0} \%$ of the label rate

The experiment was conducted in the EEA-IRGA, in Cachoeirinha, RS, using the randomized block design with three replications. Herbicide treatments were applied alone or in mixtures at rates of $50 \%$ of the maximum label rate (Table 3 ). The sowing of rice was held on November 5, 2013, with a seed density of $100 \mathrm{~kg} \mathrm{ha}^{-1}$ of IRGA 428 cultivar, in plots with $6.5 \times 2.0 \mathrm{~m}$.

\section{Evaluations and data analysis}

Evaluations of barnyardgrass control were conducted using a visual scale, according to the method EWRC (1964), where 0\% represents no effect and $100 \%$ corresponds to the death of the plants. In the first experiment, with barnyardgrass resistant to imidazolinone, evaluations were performed at 11,28 and 45 DAT (days after treatment). In the second experiment, with low rates, the evaluations were done at 5, 10 and 20 DAT. In the third, using $50 \%$ of the recommended rate, the evaluations were performed at 7, 14, 21 and 28 DAT. In both experiments, the evaluations were carried out by two trained evaluators and averaged. The rice grain yield was quantified 
Table 2 - Herbicide treatments evaluated for barnyardgrass (Echinochloa crus-galli) susceptible to imidazolinone herbicides control at low doses. Cachoeirinha-RS, 2012/13

\begin{tabular}{|c|c|c|c|c|c|}
\hline \multicolumn{2}{|c|}{ Active ingredient } & \multicolumn{2}{|c|}{ Commercial name } & \multicolumn{2}{|c|}{ Dose $\left(\mathrm{g} \mathrm{ha}^{-1}\right)$} \\
\hline Herbicide A & Herbicide B & Herbicide A & Herbicide B & Herbicide A & Herbicide B \\
\hline Clomazone & - & Gamit & - & 270.0 & - \\
\hline Clomazone & - & Gamit & - & 406.8 & - \\
\hline Propanil + thiobencarb & & Grassmax & - & $1,175.0+500.0$ & - \\
\hline Propanil + thiobencarb & & Grassmax & - & $1,762.5+750.0$ & - \\
\hline Imazethapyr + imazapic & - & Only & - & $37.5+12.5^{\underline{2} /}$ & - \\
\hline Imazethapyr + imazapic & - & Only & - & $56.3+18.8^{\frac{1 /}{}}$ & - \\
\hline Imazapyr + imazapic & - & Kifix & - & $52.5+17.5^{-2 /}$ & - \\
\hline Imazapyr + imazapic & - & Kifix & - & $78.8+26.5^{\frac{1 /}{\prime}}$ & - \\
\hline Profoxydim & - & Aura & - & $85^{2 /}$ & - \\
\hline Profoxydim & - & Aura & - & $127.5^{\frac{1 /}{}}$ & - \\
\hline Clomazone & Propanil + thiobencarb & Gamit & Grassmax & 270.0 & $1,175.0+500.0$ \\
\hline Clomazone & Propanil + thiobencarb & Gamit & Grassmax & 270.0 & $1,762.5+750.0$ \\
\hline Clomazone & Propanil + thiobencarb & Gamit & Grassmax & 406.8 & $1,175.0+500.0$ \\
\hline Clomazone & Propanil + thiobencarb & Gamit & Grassmax & 406.8 & $1,765.5+750.0$ \\
\hline Imazethapyr + imazapic & Clomazone & Only & Gamit & $37.5+12.5^{5^{2 /}}$ & 270.0 \\
\hline Imazethapyr + imazapic & Clomazone & Only & Gamit & $37.5+12.5^{\frac{2}{}}$ & 406.8 \\
\hline Imazethapyr + imazapic & Clomazone & Only & Gamit & $56.3+18.8^{1 / \prime}$ & 270.0 \\
\hline Imazethapyr + imazapic & Clomazone & Only & Gamit & $56.3+18.8^{1 /}$ & 406.8 \\
\hline Imazapyr + imazapic & Clomazone & Kifix & Gamit & $52.5+17.5^{\frac{2}{\prime}}$ & 270.0 \\
\hline Imazapyr + imazapic & Clomazone & Kifix & Gamit & $52.5+17.5^{2^{\prime}}$ & 406.8 \\
\hline Imazapyr + imazapic & Clomazone & Kifix & Gamit & $78.8+26.5^{1^{\prime \prime}}$ & 270.0 \\
\hline Imazapyr + imazapic & Clomazone & Kifix & Gamit & $78.8+26.5^{1^{\prime \prime}}$ & 406.8 \\
\hline Imazapyr + imazapic & Profoxydim & Kifix & Aura & $52.5+17.5^{2^{\prime}}$ & $85^{\frac{2}{\prime}}$ \\
\hline Imazapyr + imazapic & Profoxydim & Kifix & Aura & $52.5+17.5^{-2 /}$ & $127.5^{\frac{1 /}{}}$ \\
\hline Imazapyr + imazapic & Profoxydim & Kifix & Aura & $78.8+26.5^{1^{\prime \prime}}$ & $85^{\frac{2}{\prime}}$ \\
\hline Imazapyr + imazapic & Profoxydim & Kifix & Aura & $78.8+26.5^{1^{\prime \prime}}$ & $127.5^{\frac{1 /}{}}$ \\
\hline Imazapyr + imazapic & Propanil + thiobencarb & Kifix & Grassmax & $52.5+17.5^{-2 /}$ & $1,175.0+500.0$ \\
\hline Imazapyr + imazapic & Propanil + thiobencarb & Kifix & Grassmax & $52.5+17.5^{-2 /}$ & $1,762.5+750.0$ \\
\hline Imazapyr + imazapic & Propanil + thiobencarb & Kifix & Grassmax & $78.8+26.5^{1^{\prime \prime}}$ & $1,175.0+500.0$ \\
\hline Imazapyr + imazapic & Propanil + thiobencarb & Kifix & Grassmax & $78.8+26.5^{\frac{1}{\prime}}$ & $1,765.5+750.0$ \\
\hline Infested check & - & - & - & - & - \\
\hline
\end{tabular}

$1 / 75 \%$ of the maximum recommended dose; ${ }^{2 /} 50 \%$ of the maximum recommended dose.

based on an area of $1.7 \mathrm{~m}^{2}$, expressed at $13 \%$ moisture and extrapolated to $\mathrm{kg} \mathrm{ha}^{-1}$.

\section{RESULTS AND DISCUSSION}

The occurrence of additive, synergistic and antagonistic effects was identified at 18,18 and $64 \%$, respectively, among the total of 50 different associations of herbicide and rates evaluated. In general, the application of ALS inhibitors with ACCase inhibitors reduced the barnyardgrass control compared to the effect of the herbicides applied alone (Tables 4, 5 and 6). The mixtures of fenoxaprop-P-ethyl with imazethapyr + imazapic, imazapyr + imazapic and bispyribacsodium resulted in antagonism in most evaluations, with a significant reduction in the control of barnyardgrass resistant to ALS-inhibiting herbicides (Table 4). In susceptible biotypes, imazapyr + imazapic associated with profoxydim resulted in 
Table 3 - Herbicide treatments evaluated for barnyardgrass (Echinochloa crus-galli) susceptible to imidazolinone herbicides control applied at $50 \%$ of the recommended dose. Cachoeirinha-RS, 2012/13

\begin{tabular}{|c|c|c|c|c|c|}
\hline \multicolumn{2}{|c|}{ Active ingredient } & \multicolumn{2}{|c|}{ Commercial name } & \multicolumn{2}{|c|}{ Dose $\left(\mathrm{g} \mathrm{ha}^{-1}\right)^{*}$} \\
\hline Herbicide A & Herbicide B & Herbicide A & Herbicide B & Herbicide A & Herbicide B \\
\hline Profoxydim & - & Aura & - & 85.0 & - \\
\hline Cyhalofop-butyl & - & Clincher & - & 315.0 & - \\
\hline Imazapyr + imazapic & - & Kifix & - & $52.5+17.5$ & - \\
\hline Penoxsulam & - & Ricer & - & 31.2 & - \\
\hline Bispyribac-sodium & - & Nominee & - & 24.0 & - \\
\hline Quinclorac & - & Facet & - & 187.5 & - \\
\hline Propanil + thiobencarb & - & Grassmax & - & $2.350 .0+1.000 .0$ & - \\
\hline Clomazone & - & Gamit & - & 270.0 & - \\
\hline Profoxydim & Cyhalofop-butyl & Aura & Clincher & 85.0 & 315.0 \\
\hline Profoxydim & Quinclorac & Aura & Facet & 85.0 & 187.5 \\
\hline Cyhalofop-butyl & Quinclorac & Clincher & Facet & 315.0 & 187.5 \\
\hline Profoxydim & Clomazone & Aura & Gamit & 85.0 & \\
\hline Cyhalofop-butyl & Clomazone & Clincher & Gamit & 315.0 & 315.0 \\
\hline Imazapyr + imazapic & Profoxydim & Kifix & Aura & $52.5+17.5$ & 85.0 \\
\hline Imazapyr + imazapic & Cyhalofop-butyl & Kifix & Clincher & $52.5+17.5$ & 315.0 \\
\hline Imazapyr + imazapic & Quinclorac & Kifix & Facet & $52.5+17.5$ & 187.5 \\
\hline Imazapyr + imazapic & Propanil + thiobencarb & Kifix & Grassmax & $52.5+17.5$ & $2,350.0+1,000.0$ \\
\hline Imazapyr + imazapic & Clomazone & Kifix & Gamit & $52.5+17.5$ & 270.0 \\
\hline Penoxsulam & Profoxydim & Ricer & Aura & 31.2 & 85.0 \\
\hline Penoxsulam & Cyhalofop-butyl & Ricer & Clincher & 31.2 & 315.0 \\
\hline Penoxsulam & Quinclorac & Ricer & Facet & 31.2 & 187.5 \\
\hline Penoxsulam & Propanil + thiobencarb & Ricer & Grassmax & 31.2 & $2,350.0+1,000.0$ \\
\hline Penoxsulam & Clomazone & Ricer & Gamit & 31.2 & 270.0 \\
\hline Bispyribac-sodium & Profoxydim & Nominee & Aura & 24.0 & 85.0 \\
\hline Bispyribac-sodium & Cyhalofop-butyl & Nominee & Clincher & 24.0 & 315.0 \\
\hline Bispyribac-sodium & Quinclorac & Nominee & Facet & 24.0 & 187.5 \\
\hline Bispyribac-sodium & Propanil + thiobencarb & Nominee & Grassmax & 24.0 & $2,350.0+1,000.0$ \\
\hline Bispyribac-sodium & Clomazone & Nominee & Gamit & 24.0 & 270.0 \\
\hline $\begin{array}{l}\text { Propanil + } \\
\text { thiobencarb }\end{array}$ & Quinclorac & Grassmax & Facet & $2,350.0+1,000.0$ & 187.5 \\
\hline Propanil + thiobencarb & Clomazone & Grassmax & Gamit & $2,350.0+1,000.0$ & 270.0 \\
\hline Infested check & - & - & - & - & - \\
\hline
\end{tabular}

* $50 \%$ of the maximum dose recommended.

antagonistic effect, regardless of the evaluated rate (Table 5). In the evaluations with $50 \%$ of the herbicide rate, imazapyr + imazapic mixtures with profoxydim or cyhalofop-butyl resulted in reduction of control of barnyardgrass susceptible to ALS inhibitors (Table 6). In the same experiment, bispyribacsodium, other ALS inhibitor herbicides, when combined with profoxydim, had reduced control compared with the isolated effect of each product. However, the mixtures of penoxsulam with profoxydim or cyhalofop-butyl, and bispyribac-sodium with cyhalofop, resulted in similar control in comparison with the herbicides applied alone, resulting in an additive effect (Table 6).

The mixture of ALS- with ACCaseinhibiting herbicides is one of the main alternatives for barnyardgrass control. However, in many situations, the association of these herbicides compromised the weed 
Tabela 4 - Observed (Obs) and expected (Exp) control (\%) by Colby method of barnyardgrass (Echinochloa crus-galli) resistant to ALS inhibitors provided by herbicide mixtures evaluated at 11, 28 and 45 DAT and rice grain yield. Palmares do Sul-RS, 2010/11

\begin{tabular}{|c|c|c|c|c|c|c|c|c|}
\hline \multirow{2}{*}{ Treatament } & \multirow{2}{*}{ Dose (g ha ${ }^{-1}$ ) } & \multicolumn{2}{|c|}{$11 \mathrm{DAT}^{*}$} & \multicolumn{2}{|c|}{$28 \mathrm{DAT}$} & \multicolumn{2}{|c|}{$45 \mathrm{DAT}$} & \multirow{2}{*}{$\begin{array}{l}\text { Grain yield } \\
\left(\mathrm{kg} \mathrm{ha}^{-1}\right)\end{array}$} \\
\hline & & Obs. & Exp. & Obs. & Exp & Obs. & Exp. & \\
\hline Quinclorac + profoxydim & $375+120$ & 94 & $99 *$ & 85 & 99 & 85 & 99 & $4,055 \mathrm{ABC}$ \\
\hline $\begin{array}{l}\text { Imazapyr + imazapic e } \\
\text { profoxydim }\end{array}$ & $105+35+150$ & 91 & 95 & 75 & 93 & 90 & 92 & $5,404 \mathrm{AB}$ \\
\hline $\begin{array}{l}\text { Imazapyr + imazapic + } \\
\text { quinclorac }\end{array}$ & $105+35+375$ & 90 & $87 *$ & 96 & 96 & $96 *$ & 93 & 5,898 A \\
\hline $\begin{array}{l}\text { Fenoxaprop-P-ethyl + } \\
\text { clomazone }\end{array}$ & $89.7+400$ & 88 & 94 & 91 & 88 & 88 & 84 & $3,474 \mathrm{BC}$ \\
\hline $\begin{array}{l}\text { Fenoxaprop-P-ethyl + } \\
\text { imazapyr+ imazapic }\end{array}$ & $89.7+73.5+24.5$ & 63 & $84 *$ & 55 & $84 *$ & 48 & $79 *$ & $3,498 \mathrm{BC}$ \\
\hline $\begin{array}{l}\text { Fenoxaprop-P-ethyl + } \\
\text { bispyribac-sodium }\end{array}$ & $89.7+50$ & 68 & 87 & 64 & $85^{*}$ & 51 & $76^{*}$ & 2,884 CD \\
\hline $\begin{array}{l}\text { Fenoxaprop-P-ethyl + } \\
\text { imazethapyr + imazapic }\end{array}$ & $89.7+75+25$ & 45 & $82 *$ & 40 & $81^{*}$ & 39 & $76^{*}$ & $3,452 \mathrm{BC}$ \\
\hline $\begin{array}{l}\text { Fenoxaprop-P-ethyl + } \\
\text { penoxsulam }\end{array}$ & $89.7+48$ & 80 & 93 & 88 & 95 & 89 & $97^{*}$ & $4,020 \mathrm{ABC}$ \\
\hline Infested check & - & - & - & - & - & - & - & $2,094 \mathrm{D}$ \\
\hline
\end{tabular}

* Significant at $5 \%$ probability the $t$ test. Means followed by the same letter do not differ by Tukey test (5\%).

Table 5 - Observed (Obs) and expected (Exp) control (\%) by Colby method of barnyardgrass (Echinochloa crus-galli) provided by herbicide mixtures evaluated at 5, 10 and 20 DAT. Cachoeirinha-RS, 2012/13

\begin{tabular}{|c|c|c|c|c|c|c|c|}
\hline \multirow{2}{*}{ Treatament } & \multirow{2}{*}{ Dose $^{\underline{1} /}$} & \multicolumn{2}{|c|}{$5 \mathrm{DAT}$} & \multicolumn{2}{|c|}{$10 \mathrm{DAT}$} & \multicolumn{2}{|c|}{$20 \mathrm{DAT}$} \\
\hline & & Obs. & Exp. & Obs. & Exp. & Obs. & Exp. \\
\hline Clomazone e propanil + thiobencarb & $50+50$ & 86 & 84 & 89 & $52 * *$ & 96 & $89 *$ \\
\hline Clomazone e propanil + thiobencarb & $50+75$ & 92 & 89 & 93 & $55 * *$ & 98 & $89 *$ \\
\hline Clomazone e propanil + thiobencarb & $75+50$ & 93 & $86^{* *}$ & 94 & $56 * *$ & 98 & $89 * *$ \\
\hline Clomazonee propanil + thiobencarb & $75+75$ & 95 & $90 * *$ & 94 & $59 * *$ & 96 & $89 * *$ \\
\hline Imazethapyr + imazapic and clomazone & $50+50$ & 60 & $88^{* *}$ & 84 & $91 *$ & 97 & 99 \\
\hline Imazethapyr + imazapic and clomazone & $50+75$ & 60 & $89 * *$ & 82 & $92 * *$ & 99 & 99 \\
\hline Imazethapyr + imazapic and clomazone & $75+50$ & 64 & $91^{* *}$ & 84 & $93 * *$ & 99 & 99 \\
\hline Imazethapyr + imazapic and clomazone & $75+75$ & 66 & $92 * *$ & 86 & 93* & 99 & 99 \\
\hline Imazapyr + imazapic and clomazone & $50+50$ & 64 & $91^{* *}$ & 88 & $95 * *$ & 99 & $100^{*}$ \\
\hline Imazapyr + imazapic and clomazone & $50+75$ & 70 & $92 * *$ & 93 & $96 *$ & 99 & $100^{*}$ \\
\hline Imazapyr + imazapic and clomazone & $75+50$ & 71 & $93 * *$ & 95 & 97 & 100 & 100 \\
\hline Imazapyr + imazapic and clomazone & $75+75$ & 72 & $94 * *$ & 94 & 97 & 99 & 100 \\
\hline Imazapyr + imazapic and profoxydim & $50+50$ & 58 & $91^{* *}$ & 95 & 99 & 98 & $100 * *$ \\
\hline Imazapyr + imazapic and profoxydim & $50+75$ & 61 & $90^{* *}$ & 95 & $100^{*}$ & 98 & 100 \\
\hline Imazapyr + imazapic and profoxydim & $75+50$ & 65 & $93 * *$ & 95 & $99 * *$ & 99 & $100^{*}$ \\
\hline Imazapyr + imazapic and profoxydim & $75+75$ & 66 & $92 * *$ & 96 & $100 * *$ & 100 & 100 \\
\hline Imazapyr + imazapic and propanil + thiobencarb & $50+50$ & 78 & $85 *$ & 83 & $93 * *$ & 99 & $100^{*}$ \\
\hline Imazapyr + imazapic and propanil + thiobencarb & $50+75$ & 77 & $90 * *$ & 83 & $94 * *$ & 99 & 100 \\
\hline Imazapyr + imazapic and propanil + thiobencarb & $75+50$ & 73 & 88 & $85^{* *}$ & 95 & 99 & $100^{*}$ \\
\hline Imazapyr + imazapic and propanil + thiobencarb & $75+75$ & 72 & $92^{* *}$ & $85^{* *}$ & 96 & 99 & 100 \\
\hline Infested check & - & - & - & - & - & - & - \\
\hline
\end{tabular}

${ }^{1 /} \%$ of the recommended dose $*$ Significant at the $5 \%$ level of probability by $t$ test; ${ }^{* *}$ Significant at the $1 \%$ level of probability by $t$ test. 
control in comparison with the effect of each herbicide applied alone (Tables 4, 5 and 6). Antagonistic responses from these mixtures have been reported in other studies (Zhang et al., 2005; Blouin et al., 2010). FenoxapropP-ethyl in association with imazethapyr, penoxsulam, halosulfuron-methyl, bensulfuron or bispyribac-sodium to barnyardgrass control, or with imazethapyr, penoxsulam and bispyribac-sodium to control Urochloa platyphylla, caused a reduction of weed control (Blouin et al., 2010). This antagonistic effect was also observed in the control of barnyardgrass when used the mixtures of fenoxaprop-P-ethyl with halosulfuron-methyl or bensulfuron (Zhang et al., 2005).

The low efficiency of mixtures between ALS- and ACCase-inhibiting herbicides had been related with reduced absorption (Cobb \& Barnwell, 1994) or, in most cases, to reduced translocation of the ACCase inhibitor (Croon et al., 1989; Ferreira et al., 1995; Barnes \& Oliver, 2004). The association with DPX-PE 350, an inhibitor of the ALS enzyme, decreased the translocation of fluazifop in Digitaria sanguinalis (Ferreira et al., 1995). Similar results were observed in the translocation of fluazifop when associated with cloransulam in $U$. platyphylla (Barnes \& Oliver, 2004). In this study, the herbicide mixture decreased $40 \%$ of the translocation of fluazifop when compared with the application of this product alone.

The association of profoxydim with quinclorac reduced the control in comparison to the isolated compound in resistant biotypes (Table 4). In susceptible biotypes, the imazapyr + imazapic associations with clomazone or propanil + thiobencarb, and imazethapyr + imazapic with clomazone resulted in antagonism, regardless of the tested

Table 6 - Observed (Obs) and expected (Exp) control (\%) by Colby method of barnyardgrass (Echinochloa crus-galli) provided by herbicide mixtures evaluated at 7, 14, 21 and 28 DAT. Cachoeirinha-RS, 2013/14

\begin{tabular}{|c|c|c|c|c|c|c|c|c|}
\hline \multirow{2}{*}{ Treatament } & \multicolumn{2}{|c|}{$7 \mathrm{DAT}$} & \multicolumn{2}{|c|}{14 DAT } & \multicolumn{2}{|c|}{$21 \mathrm{DAT}$} & \multicolumn{2}{|c|}{$28 \mathrm{DAT}$} \\
\hline & Obs. & Exp. & Obs. & Exp. & Obs. & Exp. & Obs. & Exp. \\
\hline Profoxydim + cyhalofop-butyl & 93 & $86 *$ & 98 & 97 & 100 & 98 & 93 & 99 \\
\hline Profoxydime quinclorac & 88 & 91 & 86 & 96 & 80 & 95 & 86 & 95 \\
\hline Cyhalofop-butyle quinclorac & 94 & $87 * *$ & 94 & 96 & 97 & 96 & 100 & $97 * *$ \\
\hline Profoxydimeclomazone & 97 & $92 * *$ & 96 & 93 & 94 & 93 & 94 & 92 \\
\hline Cyhalofop-butyleclomazone & 83 & 88 & 91 & 94 & 84 & 94 & 87 & 94 \\
\hline Imazapyr + imazapiceprofoxydim & 68 & $89 * *$ & 96 & 98 & 100 & 100 & 100 & 100 \\
\hline Imazapyr + imazapic and cyhalofop-butyl & 77 & $85 *$ & 97 & 98 & 100 & 100 & 99 & 100 \\
\hline Imazapyr + imazapic and quinclorac & 70 & $90 * *$ & 82 & 97 & 84 & 99 & 87 & 100 \\
\hline Imazapyr + imazapic and propanil + thiobencarb & 76 & $92 * *$ & 83 & $96 * *$ & 74 & $99 * *$ & 75 & 99 \\
\hline Imazapyr + imazapic and clomazone & 84 & 91 & 98 & 96 & 100 & 99 & 100 & 99 \\
\hline Penoxsulam and profoxydim & 85 & 90 & 100 & 99 & 100 & 100 & 99 & 100 \\
\hline Penoxsulam and cyhalofop-butyl & 82 & 86 & 99 & 99 & 99 & 100 & 100 & 100 \\
\hline Penoxsulam and quinclorac & 80 & 91 & 98 & 98 & 99 & 100 & 92 & 100 \\
\hline Penoxsulam and propanil + thiobencarb & 80 & $92 *$ & 98 & 97 & 96 & $100 * *$ & 91 & 100 \\
\hline Penoxsulam and clomazone & 76 & $92 * *$ & 97 & 97 & 99 & 100 & 96 & 100 \\
\hline Bispyribac-sodium and profoxydim & 74 & 93* & 98 & 100 & 100 & 100 & 97 & 100 \\
\hline Bispyribac-sodium and cyhalofop-butyl & 79 & 90 & 95 & 100 & 100 & 100 & 98 & 100 \\
\hline Bispyribac-sodiumequinclorac & 90 & 93 & 99 & 99 & 100 & $99 * *$ & 98 & 100 \\
\hline Bispyribac-sodiumepropanil + thiobencarb & 85 & 94 & 76 & 99 & 67 & $99 *$ & 69 & 100 \\
\hline Bispyribac-sodium and clomazone & 74 & 94 & 84 & 99 & 67 & $99 *$ & 72 & 100 \\
\hline Propanil + thiobencarb and quinclorac & 82 & 93 & 57 & $91^{* *}$ & 43 & 83* & 52 & 80 \\
\hline Propanil + thiobencarb and clomazone & 82 & 93 & 58 & $85^{* *}$ & 38 & $75^{* *}$ & 22 & $66 * *$ \\
\hline Infested check & - & - & - & - & - & - & - & - \\
\hline
\end{tabular}

* Significant at the $5 \%$ of probability by $t$ test; ** Significant at the $1 \%$ of probability by $t$ test. 
dose (Table 5). The imazapyr + imazapic associations with quinclorac or propanil + thiobencarb resulted in reduced control of barnyardgrass susceptible of ALS-inhibiting herbicides (Table 6). Antagonistic results were also observed in penoxsulam associations with propanil + thiobencarb and with clomazone. Bispyribac-sodium, when combined with clomazone or propanil + thiobencarb, also resulted in reduced control. Propanil + thiobencarb associated with quinclorac or clomazone reduced the efficiency compared to the isolated effect of each product.

The synergistic effect for imidazolinone resistant barnyardgrass was also observed. Quinclorac applied in combination with imazapyr + imazapic provided better barnyardgrass control compared with products applied alone (Table 4). In the susceptible biotype, the association of clomazone with propanil + thiobencarb applied at 50 and $75 \%$ of the recommended rate also resulted in synergism (Table 5). Profoxydim mixed with cyhalofop-butyl or clomazone, and quinclorac mixture with bispyribac-sodium or cyhalofopbutyl resulted in synergism in susceptible biotype (Table 5). Quinclorac associated with profoxydim resulted in lower control in comparison with these herbicides used alone. Previous evaluations of ACCase inhibitor herbicides mixture with quinclorac had also been observed antagonism for barnyardgrass control (Blouin et al., 2010). The other herbicide mixtures evaluated exhibited additive effect (Tables 4, 5 and 6).

Grain yield varied according to the resulting weed control efficiency of the treatments (Table 4). The highest grain yields were observed in the treatment of imazapyr + imazapic in association with quinclorac. In this treatment the evidence of synergism promoted greater control of barnyardgrass and therefore less interference of the weed with the crop. The lower grain yield was observed in the treatment consisting of fenoxaprop-P-ethyl associated with bispyribac-sodium, in which there was an antagonic response. The other treatments showed intermediate grain yields. Injury effects of the treatments on irrigated rice were not observed.

The association of ALS inhibitors belonging to different chemical classes is an alternative to control imidazolinone resistant barnyardgrass or to prevent the evolution of resistance. This association increases the importance in relation to the simple change of the mechanism of action when considering the occurrence of other weeds, especially red rice. However, a hypothesis of this work is that mixtures of herbicides may cause variations in barnyardgrass control responses compared to the effect of the individual products. Furthermore, differences in the stage of weed development at the time of spraying or low effective dose reaching the weeds can result in variability of weed control. In this case, greater frequency of antagonism than synergism, or even neutral effect, on barnyardgrass control was quantified, which increases the control problem. The evaluation of 479 interactions involving 76 different weed species found antagonism predominance in monocots and synergism in dicots (Zhang et al., 1995), indicating the complexity of the effect of the herbicides association regarding the desired effects of synergy or additivity.

Some variation of response was observed in relation to the same herbicide mixture among the experiments. The association of imazapyr + imazapic with quinclorac was synergistic when evaluated in the population of resistant biotypes (Table 4) and antagonistic when assessed in susceptible biotypes (Table 6). However, in several fields of rice in southern Brazil there are barnyardgrass biotypes resistant to herbicide quinclorac (Matzenbacher et al., 2013) and this problem limit the use of quinclorac for the control of biotypes with resistance to imidazolinone herbicides. In addition, biotypes with multiple resistance to these herbicides are already present in southern Brazil (Matzenbacher et al., 2013).

The results of these studies indicate the existence of interactions which, if unknown, can cause variations in the expected weed control. The most problematic consequences are the interactions that result in antagonism. One of the alternatives to minimize the antagonistic effect, without prejudice to the control effectiveness, is the herbicide dose increase (Vidal et al. 2003; Barnes \& Oliver, 2004). In evaluations with Sorghum bicolor, the 
increasing of the dose of glyphosate reduced the antagonistic effect of mixing with triazines (Vidal et al., 2003). In other studies, increasing doses of fluazifop-P lowered the negative effect of interaction with cloransulam to control Setaria glauca (Barnes \& Oliver, 2004). Another way to avoid the antagonistic effect of these mixtures would be the application of these herbicides in isolation, with a time interval between sprays. However, both the increase of dose and the sequential application results in increasing the cost of weed control. Other barriers related to the antagonistic effects of herbicide mixtures is the need for re-application of herbicides or even reduce grain yield when re-application occurs at later stages of crop development and weed competition for environmental resources already occurred.

The problems related to the interaction of herbicides increases when observing different weed species. The interaction of fenoxapropP-ethyl with propanil, for example, resulted in antagonistic control of $E$. crus-galli and additive effect of $U$. platyphyllae and Leptochloa panicoides (Buehring et al., 2006). Similar results were observed in the association of fenoxaprop-P-ethyl with bensulfuron or halosulfuron, where the mixture provided a reduction in the effectiveness control of E. crus-galli and not for U. platyphylla (Blouin et al., 2010). Furthermore, in more controversial situations, synergistic effect occurred in the mixing lactofen with glyphosate to control Sida spinosa and Ipomoea lacunosa and antagonistic effect on the control of E. crus-galli and Sesbania exaltata (Norris et al., 2001). These negative consequences can result on increased cost of control, through the need to increase the dose or even the need for re-application of herbicides and reduced crop yields in situations where control was inefficient, as observed in the present study (Table 4).

The mixture of herbicides is a usual practice for controlling herbicide resistant weeds in the rice. The purpose of this practice is to control tolerant or resistant species to one of the mixture herbicides. However, some of the mixtures used for weed control result in antagonism, while others have a neutral or synergistic effect (Tables 4, 5 and 6).
Furthermore, the application of different herbicides mechanism of action in the same growing season may be more effective in preventing the evolution of resistance in weeds than other management practices, such as rotation of mechanisms of action over the years (Diggle et al., 2003). In the present study, we identified some effective herbicides associations to control barnyardgrass biotypes resistant to ALS-inhibiting herbicides. In general, the mixture of ACCase inhibitors, with the ALS inhibitors, or with quinclorac, clomazone + propanil or thiobencarb resulted in antagonism. Synergistic associations were found in clomazone with propanil + thiobencarb, profoxydim with cyhalofop-butyl or clomazone, and quinclorac with imazapyr + imazapic, bispyribac-sodium or cyhalofopbutyl. The association of quinclorac with profoxydim was antagonistic. These synergistic combinations may significantly contribute to weed management in irrigated rice in order to prevent the evolution and to control herbicide resistant barnyardgrass biotypes.

\section{LITERATURE CITED}

BARNES, J. W.; OLIVER, L. R. Cloransulam antagonizes annual grass control with aryloxyphenoxypropionate graminicides but not cyclohexanediones. Weed Technol., v. 18, n. 3, p. 763-772, 2004.

BARNWELL, P.; COBB, A. H. Graminicide antagonism by broadleaf weed herbicides. Pest. Sci., v. 41, n. 2, p. 77-85, 1994.

BLOUIN, D. C.; WEBSTER, E. P.; BOND, J. A. On a method of analysis for synergistic and antagonistic jointaction effects with fenoxaprop mixtures in rice (Oryza sativa). Weed Technol., v. 24, n. 4, p. 583-589, 2010.

BUEHRING, N. W.; TALBERT, R. E.; BALDWIN, F. L. Interactions of graminicides with other herbicides applied to rice (Oryza sativa). Weed Technol., v. 20, n. 1, p. 215-220, 2006.

COLBY, S. R. Calculating synergistic and antagonistic responses of herbicide combinations. Weeds, v. 15, n. 1, p. 20-22, 1967.

COUNCE, P.; KEISLING, T. C.; MITCHELL, A. J. A uniform, objective, and adaptive system for expressing rice development. Crop Sci., v. 40, n. 2, p. 436-443, 2000. 
CROON, K. A.; KETCHERSID, M. L.; MERKLE, M. G. Effect of bentazon, imazaquin and chlorimuron on the absorption and translocation of the methyl-ester of haloxyfop. Weed Sci., v. 37, n. 5, p. 645-650, 1989.

DIGGLE, A. J.; NEVE, P. B.; SMITH, F. P. Herbicides used in combination can reduce the probability of herbicide resistance in finite weed populations. Weed Res., v. 43, n. 5, p. 371-382, 2003.

EUROPEAN WEED RESEARCH COUNCIL - EWRC. Cite of methods in weed research. Weed Res., v. 4, n. 1, p. 88, 1964.

FERREIRA, K. L.; BURTON, J. D.; COBLE, H. D. Physiological-basis for antagonism of fluazifop-P by DPXPE350.Weed Sci., v. 43, n. 2, p. 184-191, 1995.

GALON, L. et al. Estimativa das perdas de produtividade de grãos em cultivares de arroz (Oryza sativa) pela interferência do capim-arroz (Echinochloa spp.). Planta Daninha, v. 25, n. 4, p. 697-707, 2007.

GAZZIERO, D. L. P. Misturas de agrotóxicos em tanque nas propriedades agrícolas do Brasil. Planta Daninha, v. 33, n. 1, p. 83-92, 2015.

GOWING, D. P. A method of comparing herbicides and assessing herbicide mixtures at the screening level. Weeds, v. 7, n. 1, p. 66-76, 1959.

HATZIOS, K. K.; PENNER, D. Interaction of herbicides with other agricultural chemicals in higher plants. Weed Sci., v. 1, n. 1, p. 1-64, 1985.

HEAP, I. International survey of herbicide resistant weeds. 2015. Disponível em: <http://www.weedscience.org>. Acesso em: 2 jan. 2015.

KRUSE, N. D. et al. Sinergismo potencial entre herbicidas inibidores do fotossistema II e da síntese de carotenóides. Ci. Rural, v. 31, n. 4, p. 569-575, 2001.

LIMPEL, L. E.; SHULDT, P. H.; LAMONT, D. Weed control by dimethyl tetrachlorotephthalate alone and in certain combination. Proc. N. Weed Control Conf., v. 16, n. 1, p. 48-53, 1962.
MATZENBACHER, F. O. et al. Distribution and analysis of the mechanism of resistance of barnyardgrass

(Echinochloa crus-galli) to imidazolinone and quinclorac herbicides. J. Agric. Sci. In press.

MATZENBACHER, F. O. et al. Rapid diagnosis of resistance to imidazolinone herbicides inbarnyardgrass (Echinochloa crus-galli) and control of resistant biotypes with alternative herbicides. Planta Daninha, v. 31, n. 3, p. 645-656, 2013.

MEROTTO JR., A.; JASIENIUK, M.; FISCHER, A. J. Estimating the outcrossing rate of Cyperus difformis using resistance to ALS-inhibiting herbicides and molecular markers. Weed Res., v. 49, p. 29-36, 2009.

MOSS, S. R.; PERRYMAN, S A M.; TATNELL, L V. Managing herbicide-resistant blackgrass

(Alopecurus myosuroides): theory and practice. Weed Technol., v. 21, n. 2, p. 300-309, 2007.

MYERS, P. F.; COBLE, H. D. Antagonism of graminicide activity on annual grass species by imazethapyr. Weed Technol., v. 6, n. 2, p. 333-338, 1992.

NORRIS, J. L.; SHAW, D. R.; SNIPES, C. E. Weed control from herbicide combinations with three formulations of glyphosate. Weed Technol., v. 15, n. 3, p. 552-558, 2001.

ROSO, A. C.; MEROTTO JR, A.; DELATORRE, C. A. Bioassays for diagnosis of resistance to the herbicides imidazolinones in rice plants. Planta Daninha, v. 28, n. 2, p. 411-419, 2010.

STRECK, E. V. et al. Solos do Rio Grande do Sul. 2.ed. Porto Alegre: Emater/RS, 2008. 222 p.

VIDAL, R. A. et al. Antagonismo na associação de glyphosate e triazinas. Planta Daninha, v. 21, n. 2, p. 301-306, 2003.

ZHANG, J. H.; HAMILL, A. S.; WEAVER, S. E. Antagonism and synergism between herbicides - trends from previous studies. Weed Technol., v. 9, n. 1, p. 86-90, 1995.

ZHANG, W. et al. Fenoxaprop interactions for barnyardgrass (Echinochloa crus-galli) control in rice. Weed Technol., v. 19, n. 2, p. 293-297, 2005. 